\title{
THE PHENOMENON OF EARLY SCHOOL LEAVING (ESL) IN GREEK EDUCATIONAL SYSTEM
}

\author{
Nikolaos Zikos \\ Adjunct Lecturer / University of Athens - Chemistry Department, \\ Teacher / Zanneio Model Junior High School \\ DOI: 10.46609/IJSSER.2020.v05i09.006 URL: https://doi.org/10.46609/IJSSER.2020.v05i09.006
}

\begin{abstract}
The Early School Leaving phenomenon (ESL) can have significant negative effects on those persons who have not completed the compulsory education of their country. In order to deal directly with this phenomenon, the EU members states (including Greece) follow goals in order to reduce its rates. In the present article a primary research was conducted using questionnaires in order to gather and present the opinions from a sample of 70 teachers, including among them four school directors and one school consultant. The study took into consideration also the current Greek economic crisis. The main solution that sample participants propose is that of the "Mathiteia" courses which allow students to extend their education for one more year, while at the same time being employed.
\end{abstract}

Keywords: Early School Leaving (ESL), Greek Educational System

\section{Introduction}

Early school leaving (ESL) can be considered as one of the major problems that Greek educational system faces especially in vocational education. Apart from Greece, this phenomenon is also observed in other European countries, resulting in an attempt in Europe to reduce the rate of ESL to $10 \%$ until 2020. Greece is one the EU states that seems to have reached the targets for the reduction of the early leavers, as they have been set by the common EU policies (mainly in general education).

Between the years of 2008 and 2015 the Greek state and the policies that the local Ministry of Education have followed, have managed to decrease the phenomenon of early leaving from education and training from $14.4 \%$ to $7.9 \%$, which amounts effectively to a reduction of about $45 \%$. In that aspect, Greece, by 2015 was together with 16 other EU countries among those that had not only achieved but were also below the EU target of 10\% (Eurostat, 2017). 


\section{International Journal of Social Science and Economic Research}

ISSN: $2455-8834$

Volume:05, Issue:09 "September 2020"

\section{Early School Leaving}

The definition used on the EU level describes the ESL phenomenon as a reference to: "...those young people who leave education and training with only lower secondary education or less, and who are no longer in education and training...' (European Commission 2013, page 8).

In order to investigate ESL globally, first and foremost we have to take into consideration the different parameters of the educational systems among the European Countries, as well as the specific characteristic that exist in each one of them. For example, one of those factors that has to be mentioned and taken into consideration, is that of the population composition and the economic status. Also we must take into consideration the fact that in some of the EU countries a high influx rate of immigrants or refugees is observed in the recent years (Pierini, 2016).

The research questions which are related in the present article are:

a) to examine the causes of ESL (especially in Greece),

b) to examine and discuss the preparation of school units in order to reduce ESL and,

c) to examine whether the ESL phenomenon is more intense after the appearance of global economic crisis since 2008, and what are the reasons that have contributed to any possible changes.

The most appropriate research approach was to conduct a form of primary research. Furthermore, the most appropriate tool in order to collect data was deemed to be the use of questionnaires that are to be distributed among teachers and directors of schools that observe the specific phenomenon.

\section{ESL and society}

ESL is viewed by many as a phenomenon that can have important economic and social consequences both on individuals and in the wider society. In order to understand the issue better, research findings have shown the broad nature of the education's benefits. Regarding individuals, education generates benefits not only because it increases the potential of their career prospects, together with their wages and job satisfaction, but also because it allows these persons to be able to handle information more efficiently, and thus be able to make more appropriate life decisions regarding their health, marriage, parenting and retirement. Furthermore, the schooling process has been also found to affect the individuals' non-cognitive skills and attitudes, such as risk aversion, patience and motivation. 


\section{International Journal of Social Science and Economic Research}

ISSN: $2455-8834$

Volume:05, Issue:09 "September 2020"

The importance of these behaviors is that they play a crucial role in a person's life, as they affect the economic choices that person undertakes. In addition, the individual's decisions for undertaking further education in the form of graduate and post-graduate forms can have social consequences, that will affect both the state's finances, as the government will have to increase tax revenues to support education possibly decreasing welfare benefit payments, as well as affect social welfare. The latter will occur as education will act as a catalyst in affecting various social situations such as the crime rates and the political participation of individuals, presumably in a manner that will bear positive results for both the person and the social environment (Oreopoulos and Salvanes, 2011).

\section{Factors that affect ESL}

The reasons that can lead to the ESL phenomenon have examined by various studies. Many of those reasons relate to the financial standing as well as the living standards of the students' family environment.

It has been found also that students, where the father is unemployed, low skilled or has a manual labor with low income, are more prone to drop out of school (Lamb, 1994; National Youth Council of Ireland, 2001). Not limited to the previous reasons, another factor that can cause the ESL phenomenon is the entrance in the labor market. Regardless if it full-time or part-time employment, the participation of students into such activities raise the possibility for them to proceed with early school leaving (Gyönös, 2011).

In that aspect, children who grew up in a family with parents who had a higher education, have lesser possibilities to drop out of school, with the opposite taking place with families with parents of low levels of education (Lamb, 1994). Cultural capital relates to the assets that a person has in terms of education and knowledge (Bourdieu \& Passeron, 1977).

Students from families with higher cultural capital tend to be more successful in school than children coming from families with less cultural capital (De Graaf \& De Graaf, 2002). Finally, the social capital of a family concerns, among other things, the relationship of the children with their parents. In the children in cases such as single parent families, or even in large families with many siblings, benefit less from their parents' resources. This has been shown to increase their probabilities for early school leaving (Heard, 2004; Nord \& West, 2001).

Another factor is that of the school composition. This is most apparent with students from ethnic minorities. This is mostly because these students face issues with the language, especially if their parents have recently migrated to the new country of residence. A second reason is that these students can draw from lower resources of cultural capital compared to their native colleagues, leading to issues with their integration in their new society. To the extent that these students can 


\section{International Journal of Social Science and Economic Research}

ISSN: $2455-8834$

Volume:05, Issue:09 "September 2020"

learn not only from their teachers, but also their colleagues, their possibilities for early school leaving decline (Van der Slik, Geert, \& De Bot, 2005).

\section{Early school leaving in Greece}

According to the relevant legislation (24136/Г7/21-2-2013) set by the Ministry of Education, parallel to the compulsory education programs, there exist parallel school activities, which provide additional teaching support. Among their main goals is also to prevent or at least limit the school dropout rates (Institute of International Relations, 2012). This indicates an actual effort by the governments for countering the ESL phenomenon.

Based on data and information collected by the Internet Information System "Myschool" in Greece the percentage of early school leavers was reduced from 9\% (2014) to 7.9\% (2015), placing it under the average of $11 \%$ which exists in the European Union (27 countries). It is remarkable that in 1982 the percentage of ESL was 25.2\%. The forecast for 2016 is that the ESL rate will decline further to about $6.5 \%$.

Despite the present crisis, this result is cause by various policies that the Ministry of Education has undertaken. Generally, ESL is minimal in primary education, as it has become compulsory, while it increase in the secondary education. The initiatives that the Ministry has proceeded even after the commencement of the crisis concern actions such as (Greek Ministry of Education, 2011):

- The introduction of a new timetable on 2011 for the all-day primary school and the introduction of new subjects for the afternoon zone.

- The provision of specific services to students with special needs in order to be part of the Greek educational system.

- Special learning support services are provided at the levels of lower secondary school and primary school through the Remedial Teaching Programs, and at the level of upper secondary school through the Additional Teaching Support Programs.

- Second Chance Schools, a form of institutions that concern citizens over 18, who have not completed the mainstream compulsory schooling period. It allows them to complete their studies even at a higher age, obtain a degree of lower secondary and mitigate any problems from social marginalization.

- Cross-cultural schools, which recognize students' particularities, cultivate mutual acceptance, exploit the cultural and language wealth that pupils carry and finally promote cross-cultural education in the framework of the local society. 


\section{International Journal of Social Science and Economic Research}

ISSN: $2455-8834$

Volume:05, Issue:09 "September 2020"

Despite the increasing attention from Ministry of Education on the issue of early school leaving, if this matter is not dealt appropriately, it might increase out of proportion. Factors such as the economic crisis could contribute further for this negative outcome (De Witte et al., 2013).

It has to be mentioned that this phenomenon can be expected to lead to an increase of the population's percentage that have only primary school certificate. According to relevant data, from the whole population that resides in Greece, approximately 2.5 million persons ( $22 \%$ of the total population) belong in the above category (UNESCO, 2015).

\section{Methodological approach of ESL}

In the article in order to investigate the phenomenon of ESL, a primary research, using questionnaires was conducted. These questionnaires were completed by a sample of teachers who either observe ESL currently in their units or had observed this phenomenon in the past.

A total sample of 70 high school teachers took part in the investigation. The sample was randomly selected. Their school units were located in the municipalities of Piraeus and Athens including central and northern regions. This way the respondents represented a number of 10 schools with an approximate total number of 4000 students. It has to be mentioned that in spite of the fact that the professors of the specific research study are currently positioned in Athens they have previous experience from isolated regions of Greece, who have higher ESL rates, because in the beginning of their careers they were placed in these regions.

\section{Analysis of findings and discussion}

The collected data were processed using Microsoft Excel program as the tool for the statistical analysis, and the results of the questionnaire are described below.

First of all we must mention that survey results are based on the responses of teachers from all educational levels of secondary education and from four different school types: general junior high schools, general senior high schools, vocational senior high schools, and vocational afternoon senior high school. The participants completed anonymous questionnaire within their school unit environment.

From the total sample of teachers (including 4 school directors and one school consultant) that took part in the specific research, 44 were male (63\%) while 26 were female (37\%). As it can be seen from Chart 4, 16 of them (23\%) are in the range 35- 44 years old, 33 of them (47\%) in the range of 45 - 54 years old and finally $21(30 \%)$ are over 55 years old. It is obvious that the educational staff in the sample is aged, as $87 \%$ of the total sample is over 45 years old. The same 


\section{International Journal of Social Science and Economic Research}

ISSN: $2455-8834$

Volume:05, Issue:09 "September 2020"

could be extrapolated for Greece, showing the need the entrance of younger teachers in the educational sector.

The school units that the study took place are vocational senior high schools, junior high schools and, senior high schools. The total number of students in these schools ranges from 200 to 300 but generally, there are also schools with more than 300 or below 100 .

From the teachers that participated in the questionnaire study, $17(24 \%)$ of them work in a junior high school, $4(5 \%)$ in a senior high school and the rest $48(71 \%)$ in vocational education. It has to be mentioned that in some cases teachers were occupied in more than one school unit (usually two schools).

Their educational experience varies. As the results show, $9(13 \%)$ of them have less than 10 years of experience, $26(37 \%)$ have 10 to 20 years, $25(36 \%)$ have 20 to 30 years and finally 10 $(14 \%)$ have more than 30 years. Of course, this conclusion is related with previous finding that the educational staff in Greece is aged.

Concerning their skills, 27 of them (38\%) hold a Master of Science degree, 14 (20\%) hold a $\mathrm{PhD}, 12(17 \%)$ have a second degree and $26(37 \%)$ hold a degree in pedagogic. In addition to that, 38 of them (54\%) hold a level A certification in computers while 21 (30\%) of them hold level B certification. From the respondents, 47 (67\%) of them speak fluently English and 23 of them (33\%) speak another language (such as German, Spanish, Italian, French and Russian). It is remarkable that only $3(4 \%)$ of them hold a certification relevant with ESL which was obtained during their studies, particularly during their Master of Science degrees.

\section{ESL in Greece - Research}

Because the sample size in this study was small (70 teachers) considering the number of high school teachers at large, the findings presented in this section should be approached with caution as these cannot be generalized to the whole population. However, some tendencies are observed and these are presented in the following sections.

Thus, $22 \%$ of the survey participants replied positively to the question that they had observed ELS phenomena in their schools. This is significantly higher than the total Greek ESL percentage that had been recorded as low as $7.9 \%$ in 2015. That said, this percentage is consistent with the ESL that is presented for the vocational schools, since during 2015 the rate at such school institutions was at around 22-23\% (Needs Analysis for Greece, 2015). Reasons that this occurs has to do probably with the low appeal that vocational education has in Greece, since it presents, especially in the past, a low linkage with the employment market. Furthermore, students especially from the rural areas of Greece opt to leave the school and join their family 


\section{International Journal of Social Science and Economic Research}

ISSN: $2455-8834$

Volume:05, Issue:09 "September 2020"

business in order to gain income. This is usual in tourist areas, such as Rhodes, where students leave school early in order to find a job in the sector of tourism or in areas in the hinterland of Greece, such as Kastoria and Ioannina, where they have a strong local production of fur or dairy products. In that aspect the phenomenon of high levels of ESL for the vocational education relates to large extent with economic reasons (Needs Analysis for Greece, 2015).

Twelve percent of the participants reported that they had experienced ELS phenomena before, while a $44 \%$ percentage stated that they have experienced such phenomena to a minimal degree or even none. Furthermore, a percentage of $30 \%$ responded that they had experienced such phenomena to a moderate degree. The fact that the majority replies that they had experienced ESL phenomena to a lesser degree in the past can mean that such phenomena have increased now. A possible reason for this can be the recent economic crisis which worsened the living standards of many families.

As it has been stated, the decline of the living standards of the household, especially when the father becomes unemployed, increased the probability for children dropping out of school, since their parents cannot provide the relevant resources, or they have to enter prematurely in to the job market (Lamb, 1994; De Graaf and De Graaf, 2002).

According to their answers these places were mainly in the islands (Ithaca, Leukada, Euboia, Salamina) and isolated regions in central Greece (Laconia, Arcadia). The fact that the ESL phenomenon appears mainly in isolated and/or rural is relevant with the findings of Kendall and Kinder (2005), and has to do with the fact that the school facilities might not be at a reasonable distance from the children's residence. This means that their families would have to incur higher costs for their school transportation, or hiring an apartment in a place near the school. Given that the options will increase the costs of the family budget, and that the other option is for the children to enter the work market, I can be seen why the families would choose the second option.

At total percentage of $38 \%$ believe that the increase of the ESL rates is caused at a large extent by the ongoing crisis. On the other hand, a percentage of $30 \%$ believes that the ESL rates are not caused at all by the crisis.

Based on the answers of the participants, the students who have higher risks for early school leaving are Students over 18 years old who are employed (23\%), with the second category being in a similar percentage of $22 \%$ and relates to students whose parents have economic problems. Their answers are consistent with the findings of Gyönös (2011), Lamb, (1994) and De Graaf and De Graaf, (2002) who examined factors such as the need of the students to enter into job 


\section{International Journal of Social Science and Economic Research}

ISSN: $2455-8834$

Volume:05, Issue:09 "September 2020"

market and have an income together with the difficulties that their families face in providing economic resources.

Given the participants refer specifically to students that are over 18, this could raise further the discussion about the need for proper and efficient implementation of second chance schools. Students from minorities or migrants come third a percentage of $21 \%$. A possible reason is that these students do not feel comfortable with their native colleagues, as they do not share the same cultural capital. It that aspect it would be preferable for the relevant authorities to follow a more inclusive policy, so that the students do not feel estranged in the school environment (Van der Slik, Geert, \& De Bot, 2005). The participants identify as the fourth category of students who face ESL risks to be those in vocational education.

As it has been stated this is consistent with the Greek educational mentality where vocational schools are held in higher esteem, as well as to the difficulties of such institutions for providing an access to the employment market (Needs Analysis for Greece, 2015). The fifth category that the participants identify is the students who have low marks (13\%), which is consistent with the findings of Alexander et al., (2001), in that the students with lower cognitive skills face higher risks for ESL. The final category that was mentioned the participants were that of the students who have bad relationships with their classmates at $6 \%$.

In the question, the respondents were requested to refer to possible solutions that would reduce the ESL phenomenon. Although the answers vary to large extent, 21\% of the respondents refer to the importance of the "Mathiteia" structures. As it was mentioned this structure offers to the students of vocational schools the chance to get educated while also getting work experience. It is understood that the respondents put forth the issue of the issue between the studies in a vocational and the linkage to the employment market, which must strength in the future. (Needs Analysis for Greece, 2015). Other respondents (17\%) bring forth once again the issue for of students from remote areas, which has been extensively discussed, while others argue that the Ministry should exercise better controls in order to see if the standards are met (15\%). A percentage of $14 \%$ raises the issue for the provision of assistance towards the students whose families face economic problems.

Also, a percentage of the respondents proposes the creation of services relevant to ESL in the municipalities, while $10 \%$ asks for the creation of more schools. Furthermore, $12 \%$ of the respondents propose "other" solutions such as the reduction of curriculum courses (especially in vocational education and in $\mathrm{C}$ class), flexibility in absences (perhaps a small increase for students who combine work with education) and improved means of transportation for students who are forced to travel in order to reach their school or the chance to be hosted in the capital of the region where the school is located, especially in the case of isolated regions. 


\section{International Journal of Social Science and Economic Research}

ISSN: $2455-8834$

Volume:05, Issue:09 "September 2020"

\section{Conclusions}

The aim of the present exploratory research is to preliminary investigate and propose ways to decrease and eventually prevent ESL mainly in Greek educational system. Although the sample size is small however certain tendencies can be observed based on the responses of the study participant. In the future (school year 2020-2021 a further investigation will take place, taking into consideration the Covid-19 pandemic ant its consequences on ESL).

According to the actions of Ministry of Education, which were also mentioned in the interviews, the main step towards ESL prevention is to start by collecting realistic data on a national level from schools (through "Myschool" online system mainly) and categorize them accordingly based on the type of education (general or vocational), location (big cities or isolated regions) and demographic characteristics of students (possible economic difficulties, origin from other countries etc).

In the Greek national level there is the 'Strategic Policy Framework for the Elimination of ELET' whose main aim is the establishment of a system of second chance schools, in order to give early school leavers a second chance in education (European Commission, 2016b). This action does not reduce ESL for all students, but it can still be considered as an alternative solution, especially for students over eighteen years old and shows the great importance that the Ministry of Education places on the problem of ESL. The main action is establishment of at least a second chance school in every region (totally 54 in Greece). Parallel to this very important is the extension of "Mathiteia" structure and a stronger connection between vocational education and labor market.

According to sample participants responses it seems that ESL is mainly observed among students of vocational education, where many of them are above 18 years old, students who face financial problems in their families and are forced to work in parallel with their studies, or students who come from a foreign country. The percent of the latter can be expected to increase in the future due to the refugee crisis.

Finally the most appropriate solution is strengthening of counseling institutions. Educational systems in Europe, besides the basic education, offer also career guidance, in the form of counseling, during the education process in order to limit/prevent the ESL phenomenon. Internal school guidance services have to be provided in all European countries and especially during the C class of Junior High Schools, in order for the students to choose whether they will follow general or vocational education, as well as in the A class of Senior High Schools, in order to choose their orientation in general and specialization in vocational education, and $\mathrm{C}$ class of Senior High Schools, in order to choose the appropriate department in tertiary education. 


\section{International Journal of Social Science and Economic Research}

ISSN: $2455-8834$

Volume:05, Issue:09 "September 2020"

\section{References}

[1] Bourdieu, P., \& Passeron, J. C., (1977), "Reproduction in education, society and culture". London: Sage.

[2] De Graaf, N. D., \& De Graaf, P. M. (2002), "Formal and popular dimensions of cultural capital: Effects on children's educational attainment ",The Netherlands' Journal of Social Sciences, 38(2), pp. 167-186.

[3] De Witte K., Cabus S. J., Thyssen, G., \& Maassen Vandenbrink L. H., (2013), “A Critical Review of the Literature on School Dropout", Educational Research Review, Volume 10, pp. 1328

[4] Eurostat (2017), "Europe 2020 indicators - education", Eurostat Statistics Explained<available at http://ec.europa.eu/eurostat/statisticsexplained/index.php/Europe_2020_indicators_-_education>, [accessed on 29/03/2020]

[5] European Commission, (2013), "Progress in tackling early school leaving and raising higher education attainment - but males are increasingly left behind", European Commission, Pres Release, available at http://europa.eu/rapid/press-release_IP-13-324_en.htm, [accessed on $10 / 06 / 2020]$

[6] European Commission / EACEA / Eurydice, (2016). Compulsory Education in Europe 2016/17. Eurydice Facts and Figures. Luxembourg: Publications Office of the European Union, <available on http://www.anefore.lu/wp-content/uploads/2016/10/EURYDICE-COMPULSORYEDUCATION.pdf>, [accessed on 20/03/2020]

[7] Greek Ministry of Education, (2011), "2011 National Report on the Implementation of the Strategic Framework for European Cooperation in Education and Training; Hellas", Ministry for Education, Lifelong Learning and Religious Affairs, available at https://www.google.gr/url?sa=t\&rct=j\&q=\&esrc=s\&source=web\&cd=9\&ved=0ahUKEwjts5_19r jUAhXEuBQKHWEeAWMQFghYMAg\&url=https\%3A\%2F\%2Fwww.iky.gr\%2Fen\%2Fecvetnetwork\%2Fitem\%2Fdownload\%2F2020_5acef6bae99c179554473d81b3ce4d20\&usg=AFQjCN H-T1xEwkyZzUeNaoRk37bh2yg7Nw\&sig2=YQ8z6RinfXn241GKYte5Jg\&cad=rja, [accessed on $10 / 06 / 2020]$

[8] Gyönös E., (2011), "Early School Leaving Reasons and Consequences", Theoretical and Applied Economics Volume XVIII, No. 11 (564), pp. 43-52

[9] Heard, H. E. (2004). "The life course of family structure and adolescent school achievement: Racial and ethnic differences", Unpublished Paper presented at the Population Association of America 2004 meeting, Boston.

[10] Institute of International Relations, (2012), "Immigration of international students to the EU", European Migration Network, <available on https://ec.europa.eu/homeaffairs/sites/homeaffairs/files/what- 
wedo/networks/european_migration_network/reports/docs/emn-studies/immigrationstudents/17._luxembourg_national_report_internationalstudents_march2013_final_en.pdf> [11] Lamb, S. (1994). "Dropping out of school in Australia: Recent trends in participation and Outcomes". Youth and Society, 26 (2), pp.194-222.

[12] Needs Analysis for Greece, (2015), "NET not NEET", Hellenic Republic, Ministry of Culture, Education And Religious Affairs, available at http://thess.pde.sch.gr/jn/eu_progs/nnn/NNN_Need\%20Analysis\%20Report_GR2.pdf, [accessed on $10 / 06 / 2020$ ]

[13] Nord, C. W., \& West, J. (2001), 'Fathers' and others' involvement in their children's schools by family type and resident status". Washington, DC: U.S. Department of Education. National Center for Education Statistics

[14] Oreopoulos P., \& Salvanes K. G. (2011), "Priceless: The Non pecuniary Benefits of Schooling" Journal of Economic Perspectives, Vol. 25, No.1, pp. 159-84

[15] Pierini M., (2016), "In Search of an EU Role in the Syrian War", Carnegie Europe,, available on http://carnegieeurope.eu/2016/08/18/in-search-of-eu-role-in-syrian-war-pub64352>, [accessed on 24/03/2020]

[16] UNESCO, (2015), "Education for All 2015 National Review", National EFA 2015 Reviews, <http://unesdoc.unesco.org/images/0022/002299/229950E.pdf>, [ available on $12 / 03 / 2020]$

[17] Van der Slik, F. W. P., Geert, W. J. M., \& De Bot, K. L. J. (2005), Ethnic and Socioeconomic Class Composition and Language Proficiency: a Longitudinal Multilevel Examination in Dutch Elementary Schools", European Sociological Review, 223,(293-308). 